\title{
Ionic interactions of anionic thiacalix[4]arene with cationic porphyrins $^{\#}$
}

\author{
Bhaskar Garg, Tanuja Bisht, and Shive Murat Singh Chauhan* \\ Bioorganic Research Laboratory, Department of Chemistry, University of Delhi, Delhi-110007, \\ India \\ E-mail: smschauhan@chemistry.du.ac.in
}

DOI: $\underline{\text { http://dx.doi.org/10.3998/ark.5550190.0011.212 }}$

\begin{abstract}
A facile synthesis of 25,26,27,28-tetrakis(alkyloxy)-2,8,14,20-tetrathiacalix[4]arene-5,11,17,23tetrasulfonate via ipso substitution of p-tert-butylthiacalix[4]arene tetraalkyl ether with sulfuric acid is described. Ionic interaction of anionic thiacalix[4]arene and cationic porphyrins were quantitatively studied by UV-vis, fluorescence, ${ }^{1} \mathrm{H}$ NMR and ESI-MS spectrometry. Binding constants were in the range of $10^{8} \mathrm{M}^{-1}$. Binding with axial ligands was investigated and formation of ternary complexes was recognized with pyridine, 4-methylpyridine and $\mathrm{N}$ methylimidazole. The factors affecting the interaction process including $\mathrm{pH}$, solvents and salts were also examined in detail. The results indicated that the neutral medium $(\mathrm{pH}=7)$ is most favorable for electrostatic interactions.
\end{abstract}

Keywords: Ionic interaction, anionic thiacalix[4]arene, cationic porphyrin, supramolecular assembly

\section{Introduction}

Supramolecular capsules present an important class of architectures that can reversibly accommodate smaller molecules in their cavities. ${ }^{1}$ The synthesis of molecular capsules, ${ }^{2}$ based on ionic interactions between oppositely charged calix[4]arenes (C[4]A) is useful for biochemical applications such as drug encapsulation, transport through cell membrane, drug delivery and so far their use has been explored in the stabilization of reactive intermediates for organic transformations and for catalysis. ${ }^{3}$ These capsules consist of two or more building blocks that have similar size, complementary functional groups and associate via multiple non-covalent interactions such as H-bonds, ${ }^{4}$ metal ligands ${ }^{5}$ and ionic interactions. ${ }^{6}$ A wide variety of homo and

\# A part of this work has been presented at CRSI $9^{\text {th }}$ National Symposium in Chemistry, Delhi, Feb 1-4, 2007 
hetero capsules based on functionalized calixarenes (CA), resorcinarenes and other building blocks have been reported. ${ }^{7}$ Water soluble cationic porphyrins are currently of vast interest because of their possible wide applications such as self-assembled nanostructures with welldefined shapes and dimensions, in photochemical cleavage of DNA, in water splitting reactions and as mimic of energy transfer systems. ${ }^{8}$ Cationic meso-5,10,15,20-tetrakis $(N$-methyl-4pyridyl)porphyrin has affinity to bind G-quadruplex DNA, has been the focus of a new avenue for the treatment of cancer. ${ }^{9}$

The CA are third generation host molecules supplementing the crown ethers ${ }^{10}$ and cyclodextrins. ${ }^{11}$ The presence of four sulfur atoms imposes many new properties on the Thiacalix[4]arene (TC[4]A) skeleton as compared to classical C[4]A. Several reactions, ${ }^{12}$ unknown in C[4]A chemistry have been described due to the intrinsic properties of sulfur such as coordination ability to metal ions, oxidizability to sulfoxide and sulfone, the larger size, reactivity and increased fluxionality than those of the $-\mathrm{CH}_{2}$ bridged $\mathrm{C}$ [4]A skeleton. The covalently linked TC[4]A with porphyrins leads to novel conjugates, which exhibit complexation abilities towards anions, ${ }^{13}$ cations ${ }^{14}$ or neutral molecules. ${ }^{15}$ Interaction of C[4]A with porphyrins via covalent bonding, ${ }^{16} \mathrm{H}$-bonding ${ }^{17}$ and ionic interactions ${ }^{18}$ have been well explored but to the best of our knowledge there is no report of ionic interaction between anionic TC[4]A and cationic porphyrins. Thiacalixarenes are essentially insoluble in water, and therefore the introduction of sulfonate functions at the upper rim would enable the extension of their chemistry into aqueous solutions, a requirement for potential biological applications. Although, ipsosulfonation of tetrahydroxythiacalix[4] arene with conc. $\mathrm{H}_{2} \mathrm{SO}_{4}$ at $90^{\circ} \mathrm{C}$ is well known, ${ }^{19}$ there is no report for the ipso sulfonation of tetraether derivative of TC[4]A.

Herein, we report the synthesis of anionic 25,26,27,28-tetrakis(n-butyloxy)-2,8,14,20tetrathiacalix[4]arene-5,11,17,23-tetrasulfonate $\mathbf{4 a}$ and 25,26,27,28-tetrakis(n-hexyloxy)2,8,14,20-tetrathiacalix[4]arene-5,11,17,23-tetrasulfonate $\mathbf{4 b}$ which strongly interact with cationic water soluble porphyrins 1a-1g under different conditions owing to multiple electrostatic interactions. The aim of this paper is to develop the supramolecular assembly of cationic porphyrins 1a-1g and anionic tetrasulfonatothiacalix[4]arene $\mathbf{4 a}$ and $\mathbf{4 b}$ (Figure 1) based on spectroscopy. It is well known that the cavity of the thiacalix[4]arene $\mathbf{4}$ is bigger than the ordinary C[4]A, thus the self-assembled complex can provide a larger cavity with potential as supramolecular hosts and model structure for biomimetic investigations.

\section{Results and Discussion}

\section{Spectral characterization}

The reaction of TC[4]A 2 with excess of alkyl bromides in the presence of $\mathrm{NaH}$ in acetone under reflux for $20 \mathrm{~h}$ gave the thiacalix[4]arenes 3 in 55-60\% yields (Scheme 1). In the IR spectra, the disappearance of $3324 \mathrm{~cm}^{-1}$ band, corresponding to -OH group of TC[4]A supported that all the hydroxyl groups on the lower rim were converted into alkyloxy groups. The appearance of singly 
charged $[\mathrm{M}+\mathrm{Na}]^{+}$peak at $967.5845 \mathrm{Da}$ in the ESI-mass spectrum supported the formation of the tetra-tert-butylated thiacalix[4]arene 3a.
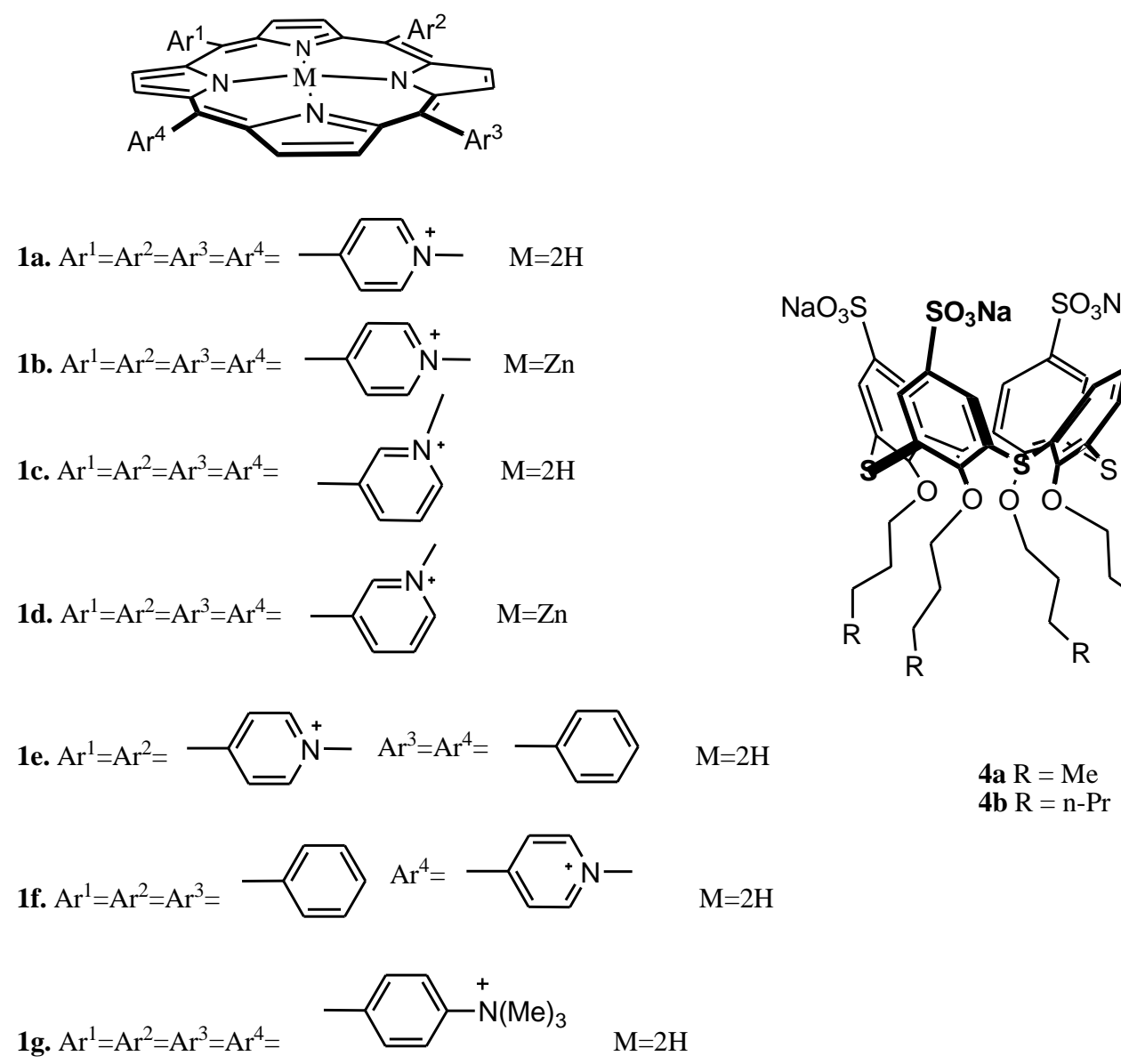

Figure 1. Molecular building blocks for ionic interaction.

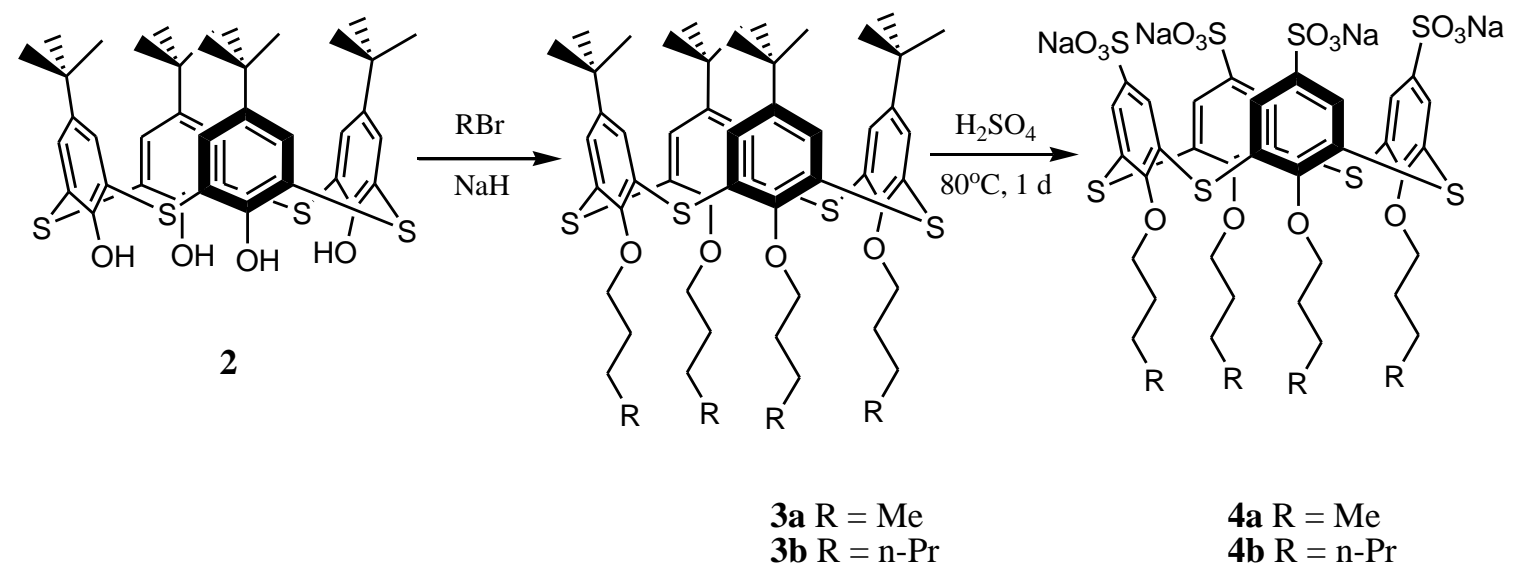

Scheme 1. Synthesis of anionic thiacalix[4]arenes $\mathbf{4 a}$ and $\mathbf{4 b .}$ 
The ${ }^{1} \mathrm{H}$ NMR spectrum of the thiacalix[4] arene 3a in $\mathrm{CDCl}_{3}$ displayed a very simple profile. In particular, the resonance at $\delta 1.27(36 \mathrm{H})$, a sharp singlet at $\delta 7.30(8 \mathrm{H})$ and a triplet at $\delta 3.80$ ppm $(8 \mathrm{H})$ were assigned for $\mathrm{t}-\mathrm{Bu}$, aromatic protons and $-\mathrm{OCH}_{2}$ protons, respectively. Furthermore, the ${ }^{13} \mathrm{C}$ NMR spectra of the thiacalix[4]arene 3a showed characteristic peaks at $\delta$ 67.90, 34.00 and $\delta 156.57$ ppm for $\mathrm{OCH}_{2}, \mathrm{t}-\mathrm{Bu}$ and $\underline{\mathrm{C}}_{\mathrm{Aro}}-\mathrm{OC}_{4} \mathrm{H}_{9}$, respectively. Thus the presence of only one singlet $\left(8 \mathrm{H}\right.$, aromatic) in ${ }^{1} \mathrm{H}$ NMR spectrum and twelve resonances in ${ }^{13} \mathrm{C}$ NMR spectrum of the thiacalix[4]arene 3a ruled out the possibility of other conformations except either 1,3-alternate or cone conformation. To ensure the exact conformation, the NOESY spectrum of 25,26,27,28-tetrakis(butyloxy)-2,8,14,20-tetrathiacalix[4]arene-5,11,17,23-tetra(tertbutyl)calix[4] arene 3a was recorded in $\mathrm{CDCl}_{3}$ (Figure 2).

As can be seen from Figure 2, the aromatic protons showed non-bonded interaction with only tert-butyl protons. If the compound exists in 1,3-alternate form, there would have been some type of interaction between aromatic and butyl chain protons. Thus, keeping this fact, it was confirmed that compound 3a exists only in cone conformation and not in the 1,3-alternate form. Similar observations were made with $\mathbf{3 b}$.

The 25,26,27,28-tetralkyloxy-2,8,14,20-tetrathiacalix[4]arene-5,11,17,23-tetra-sulfonates 4 were synthesized by the reaction of 25,26,27,28-tetralkyloxy-2,8,14,20-tetrathiacalix[4]arene 3 with $\mathrm{H}_{2} \mathrm{SO}_{4}$ at $80^{\circ} \mathrm{C}$. The reaction mixtures were neutralized with $\mathrm{BaCO}_{3}$ and the $\mathrm{pH}$ of the filtrates were adjusted to 7.5-8.0 with $\mathrm{Na}_{2} \mathrm{CO}_{3}$ solution. The filtrates were distilled under reduced pressure and the desired compounds were precipitated analytically pure by addition of ethanol.

In the IR spectrum, the 25,26,27,28-tetrakis(hexyloxy)-2,8,14,20-tetrathia-calix[4]arene$5,11,17,23$-tetrasulfonate $4 \mathbf{b}$ showed a characteristic band at $1193 \mathrm{~cm}^{-1}$ which was assigned for $\mathrm{SO}_{3}$ groups. The disappearance of proton signals at $\delta 1.19 \mathrm{ppm}(\mathrm{s}, \mathrm{t}-\mathrm{Bu}, 36 \mathrm{H})$ in the ${ }^{1} \mathrm{H} \mathrm{NMR}$ spectrum of $\mathbf{4 b}$ clearly indicated the ipso-sulfonation of parent compound. Moreover, the appearance of a new resonance at $\delta 146.73\left(\underline{\mathrm{C}}-\mathrm{SO}_{3} \mathrm{Na}\right)$ and disappearance of resonances at 34.19 $(\mathrm{t}-\mathrm{Bu})$ and $31.32 \mathrm{ppm}(\mathrm{t}-\mathrm{Bu})$ in ${ }^{13} \mathrm{C}$ NMR spectrum, further confirmed the formation of $\mathbf{4 b}$. The spectroscopic analysis revealed that tetrasulfonated thiacalix[4]arene $\mathbf{4 b}$ also exists in cone conformation. 

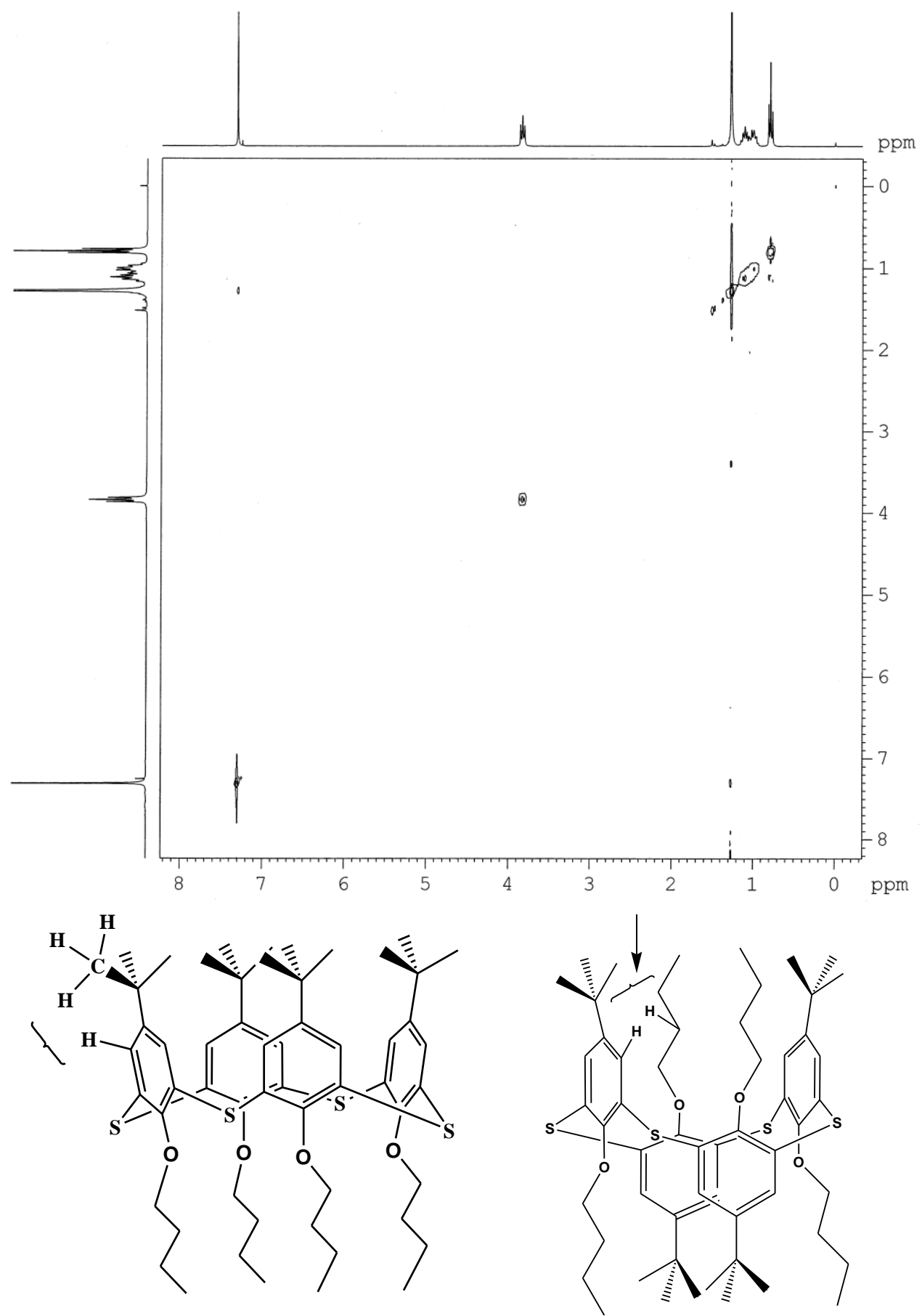

Cone conformation

(possible)
1,3-Alternate conformation

(not possible)

Figure 2. NOESY spectrum of $\mathbf{3 a}$ in $\mathrm{CDCl}_{3}$. 


\section{Ionic interaction studies}

UV-vis spectroscopy. The influence of anion-cation interactions on the structure and electronic absorption spectra of cationic porphyrins and anionic thiacalix[4]arenes were investigated by absorption spectroscopy. Solutions of porphyrins $\left(\mathbf{1 a - 1 g}, 2.0 \times 10^{-7} \mathrm{M}\right)$ in water $(2.5 \mathrm{~mL})$ were titrated with increasing volumes of anionic thiacalix[4]arenes 4. Stepwise addition of compound 4b to porphyrins 1a-1g resulted in pronounced UV-vis spectral changes. A typical example is shown in Figure 3. Thus, the intensities of the Soret band at $428 \mathrm{~nm}$ (corresponding to the porphyrin B transition) and visible bands (corresponding to the porphyrin Q transitions) of the porphyrins gradually decreased upon increasing the concentration of the thiacalix[4]arene $\mathbf{4 b}$ and new bathochromically shifted (by 3-8 nm) B- and Q-bands appeared. At the same time two clear isobestic points were observed at $390 \mathrm{~nm}$ and $438 \mathrm{~nm}$ in the Soret region. The 1:1 stoichiometry was observed for the porphyrin:thiacalix[4]arene assemblies by method of continuous variation. The absorption spectroscopic titrations gave the apparent binding constants (Table 1).

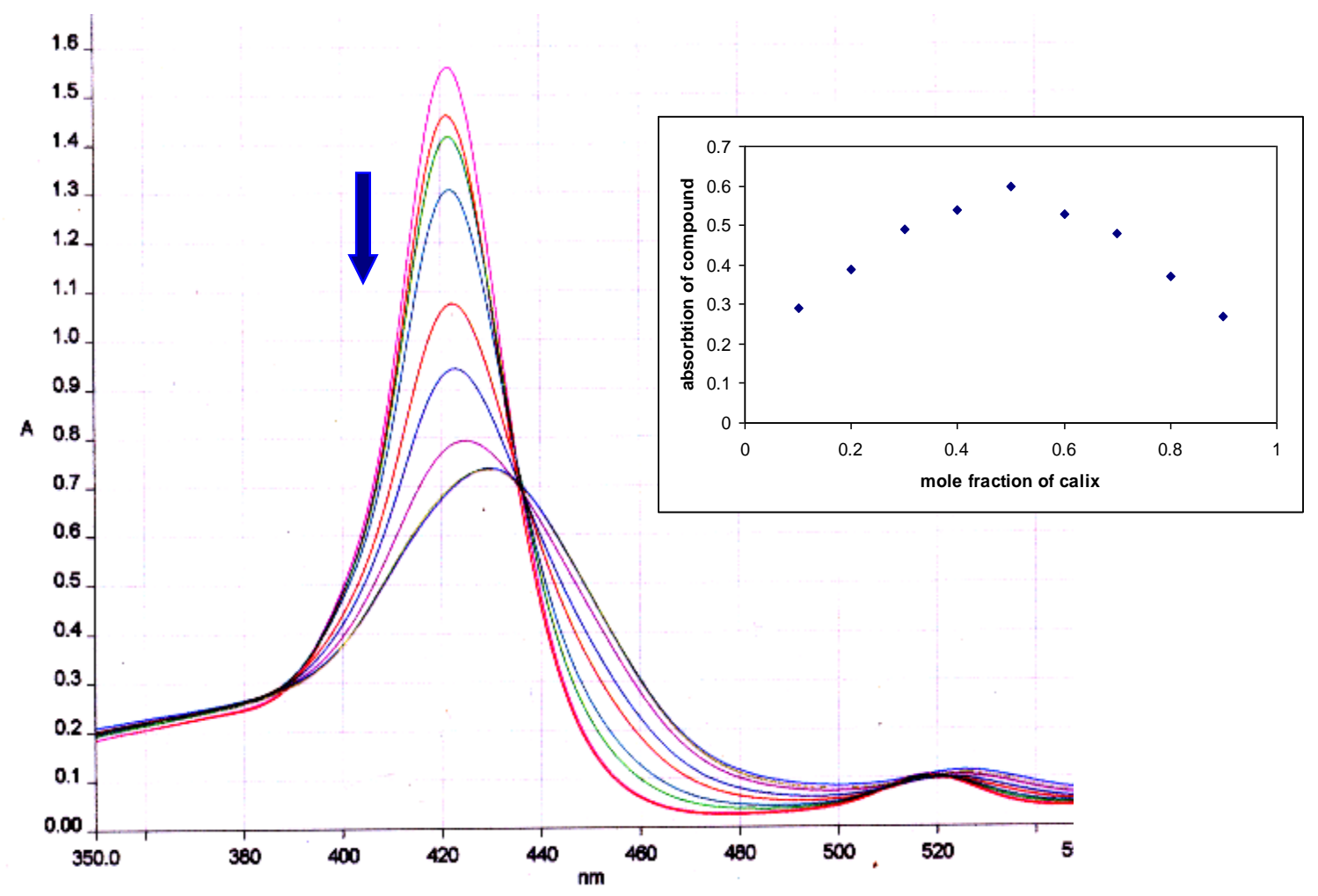

Figure 3. UV-Vis spectra of porphyrin $1 \mathbf{b}\left(2 \times 10^{-7} \mathbf{M}\right)$ on titration with thiacalix[4] arene $\mathbf{4 b}(0.2$ $\times 10^{-7} \mathbf{M}$ to $4 \times 10^{-7} \mathrm{M}$ ) in water at $\mathrm{pH} 7$; Inset: Job plot of $\mathbf{1 b}$ titrated with $\mathbf{4 b}$. 
Table 1. Binding constants $\left(K_{\text {ass }}\right)$ calculated for ionic interaction between cationic porphyrin 1a$\mathbf{1 g}$ and anionic thiacalix[4]arenes $4 \mathbf{a}$ and $4 \mathbf{b}$ at $25^{\circ} \mathrm{C}$

\begin{tabular}{|c|c|c|c|c|}
\hline Entry & Porphyrin (1) & $\mathrm{pH}$ & Solvent & Binding constant $\left(\mathrm{M}^{-1}\right)$ \\
\hline 1 & $1 a .4 a$ & 7.0 & $\mathrm{H}_{2} \mathrm{O}$ & $3.9 \times 10^{7 \mathrm{a}}\left(1.9 \times 10^{7}\right)^{\mathrm{b}}$ \\
\hline 2 & $1 \mathrm{a} .4 \mathrm{~b}$ & 7.0 & $\mathrm{H}_{2} \mathrm{O}$ & $4.2 \times 10^{7 a}\left(9.8 \times 10^{6}\right)^{b}$ \\
\hline 3 & 1b.4b & 7.0 & $\mathrm{H}_{2} \mathrm{O}$ & $1.6 \times 10^{7 a}\left(8.7 \times 10^{6}\right)^{b}$ \\
\hline 4 & $1 c .4 b$ & 7.0 & $\mathrm{H}_{2} \mathrm{O}$ & $3.3 \times 10^{7 a}\left(1.6 \times 10^{7}\right)^{b}$ \\
\hline 5 & $1 \mathrm{~d} .4 \mathrm{~b}$ & 7.0 & $\mathrm{H}_{2} \mathrm{O}$ & $3.5 \times 10^{6 a}\left(1.2 \times 10^{6}\right)^{b}$ \\
\hline 6 & $1 \mathrm{e} .4 \mathrm{~b}$ & 7.0 & $\mathrm{H}_{2} \mathrm{O}$ & $\mathrm{nd}^{\mathrm{c}}$ \\
\hline 7 & 1f.4b & 7.0 & $\mathrm{H}_{2} \mathrm{O}$ & $\mathrm{nd}^{\mathrm{c}}$ \\
\hline 8 & $1 g .4 b$ & 7.0 & $\mathrm{H}_{2} \mathrm{O}$ & $2.1 \times 10^{8 \mathrm{a}}$ \\
\hline 9 & 1c. $4 \mathrm{~b}$ & - & $\mathrm{MeOH} *$ & $5.3 \times 10^{8 a}$ \\
\hline 10 & 1c. $4 \mathrm{~b}$ & - & $\mathrm{MeOH}: \mathrm{H}_{2} \mathrm{O}$ & $8.7 \times 10^{7 a}$ \\
\hline 11 & 1c. $4 \mathrm{~b}$ & - & DMSO & $4.5 \times 10^{5 \mathrm{a}}$ \\
\hline 12 & 1b.4b & 4.0 & $\mathrm{H}_{2} \mathrm{O}^{\mathrm{d}}$ & $7.5 \times 10^{6 a}$ \\
\hline 13 & 1b.4b & 7.0 & $\mathrm{H}_{2} \mathrm{O}^{\mathrm{d}}$ & $2.7 \times 10^{7 a}$ \\
\hline 14 & 1b.4b & 9.2 & $\mathrm{H}_{2} \mathrm{O}^{\mathrm{d}}$ & $9.2 \times 10^{6 \mathrm{a}}$ \\
\hline 15 & $1 \mathrm{~d} .4 \mathrm{~b}$ & 4.0 & $\mathrm{H}_{2} \mathrm{O}^{\mathrm{d}}$ & $3.8 \times 10^{5 \mathrm{a}}$ \\
\hline 16 & $1 d .4 b$ & 7.0 & $\mathrm{H}_{2} \mathrm{O}^{\mathrm{d}}$ & $2.9 \times 10^{6 a}$ \\
\hline 17 & $1 \mathrm{~d} .4 \mathrm{~b}$ & 9.2 & $\mathrm{H}_{2} \mathrm{O}^{\mathrm{d}}$ & $8.2 \times 10^{5 \mathrm{a}}$ \\
\hline 18 & $1 c .4 b$ & 7.0 & $\mathrm{H}_{2} \mathrm{O}(\mathrm{NaCl})$ & $7.9 \times 10^{7 a}$ \\
\hline 19 & 1c. $4 \mathrm{~b}$ & 7.0 & $\mathrm{H}_{2} \mathrm{O}\left(\mathrm{NaClO}_{4}\right)$ & $6.9 \times 10^{7 a}$ \\
\hline
\end{tabular}

${ }^{\mathrm{a}}$ Determined by absorption spectroscopic titrations; ${ }^{\mathrm{b}}$ determined by fluorescence spectroscopic titrations. Errors are less than $\pm 18 \%$; ${ }^{\mathrm{c}}$ nd $=$ not determined; ${ }^{\mathrm{d}}$ all $\mathrm{pH}$ solutions were prepared in phosphate buffer. * Ionic interaction studies between classical C[4]A and porphyrins gave lower value of $\mathrm{K}_{\mathrm{ass}}\left(\sim 10^{7} \mathrm{M}\right)$ in $\mathrm{MeOH}$ : see ref. $18 \mathrm{~b}$.

From Table 1, it is clear that metal free porphyrins strongly bind with TC[4]A. This is presumably due to the greater flexibility of the metal free porphyrins vs the metallated porphyrins. Metal centers were available for ligand binding as well as for $\mathrm{pH}$ effects. Porphyrin $1 \mathrm{~g}$ strongly binds with $\mathbf{4 b}$ relative to porphyrins $1 \mathbf{a}$ and $\mathbf{1 c}$ because in $1 \mathbf{a}$ and 1c, the charges are in the rings while in 1g, the positive charge on external nitrogen increases the size of the porphyrin and easily available for negative charges of anionic TC[4]A. Porphyrin 1b somewhat strongly binds with $\mathbf{4 b}$ than $\mathbf{1 d}$ due to the close proximity of 4-pyridyl cationic nitrogen with the anionic part of TC[4]A. Porphyrin 1c exists in four different atropisomeric forms ( $\alpha \alpha \alpha \alpha, \alpha \alpha \alpha \beta$, $\alpha \alpha \beta \beta, \alpha \beta \alpha \beta)$ due to the non-symmetric substitution at the meso aromatic rings. Ionic interactions induced by anionic TC[4]A forces all molecules to convert only to the $\alpha \alpha \alpha \alpha$ form. On the contrary, the spectral changes of 5,15-bis( $N$-methyl-4-pyridinium)-10,20-diphenylporphyrin 1e and mono-(4-pyridyl)-triphenylporphyrin $\mathbf{1 f}$ with $\mathbf{4 b}$ were not sufficient to determine reasonable 
binding constants. The results indicate that a change of the alkyl chain has almost no effect on the strength of the ion pair complex (entry 1 and 2). In order to exclude the possibility that the observed spectral changes are due to nonspecific aggregation of porphyrins 1a-1g, the UV-vis spectra of porphyrins 1a-1g were measured at various concentrations (between $10^{-7}$ and $10^{-6} \mathrm{M}$ in $\mathrm{H}_{2} \mathrm{O}$ ). Aggregation of the porphyrins was not observed at this concentration range.

\section{Ligand binding}

The coordination of axial ligands $\mathbf{L}$ to the zinc center of assembly, forming ternary complexes was also studied. Zinc porphyrins are known to bind only one axial ligand resulting in a fivecoordinated zinc atom. ${ }^{20}$ In order to demonstrate the binding ability of the complex, binding studies were performed in $\mathrm{H}_{2} \mathrm{O}$ with pyridine, 4-methylpyridine and $\mathrm{N}$-methylimidazole ligands. In all the cases, the binding of ligands $\mathbf{L}$ with $\mathrm{Zn}$-porphyrins was accompanied by bathochromic shifts and with noticeable decreases in the chromophoric basic absorption bands (Figure 4).

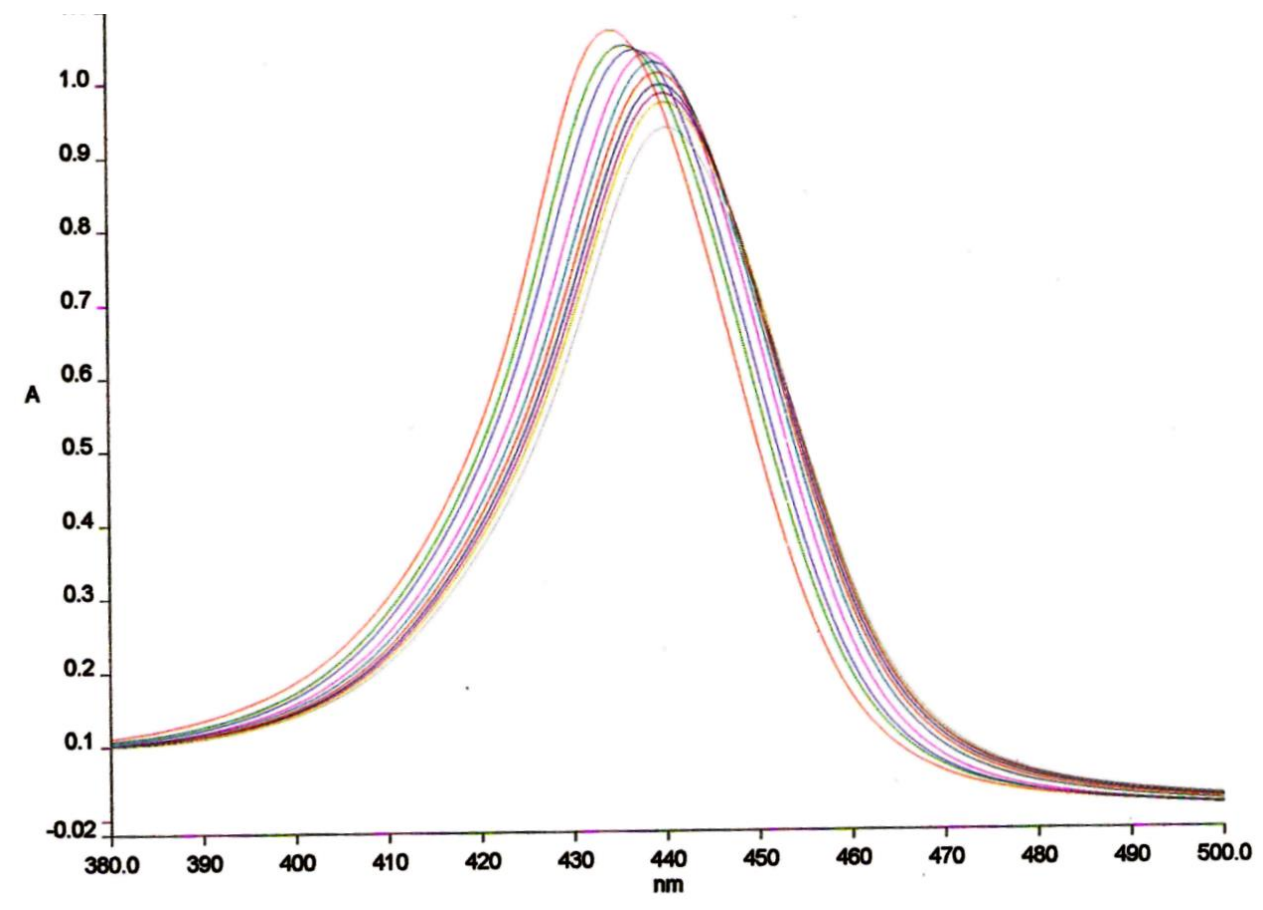

Figure 4. UV-Vis spectra of complex $\mathbf{1 b . 4 b}\left(2 \times 10^{-7} \mathrm{M}\right)$ on titration with $N$-methyl-imidazole $\left(0.2 \times 10^{-7} \mathrm{M}\right.$ to $\left.2 \times 10^{-7} \mathrm{M}\right)$.

Presumably, this was due to the increase of electron density at the zinc cation and at the porphyrin nitrogen atoms. The growth of a fractional negative charge at $\mathrm{N}$ atoms establishes the destabilization of the $a 2 u$ molecular orbital at $a 1 u$ constant level. The bathochromic shift, probably, was caused by the increase in the energy of $a 2 u$ - type MO. Upon addition of increasing amount of ligand to the solution of porphyrins $\mathbf{1 b}$ and $\mathbf{1 d}$ in $\mathrm{H}_{2} \mathrm{O}\left(2 \times 10^{-7} \mathbf{M}\right)$, characteristic Soret peak at $430 \mathrm{~nm}$ of porphyrin changed with 5-7 nm bathochromic shifting. 
Porphyrin $\mathbf{1 b}$ showed augmented affinity towards $N$-methylimidazole and 4-methylpyridine than pyridine itself. Moreover, UV-vis titrations of a 1:1 complex of porphyrin and TC[4]A showed the formation of a 1:1:1 complex with axial ligands as confirmed by Job's method.

Association constants for ligand complexation are tabulated in Table 2. In particular, binding of 4-methylpyridine and $\mathrm{N}$-methylimidazole was very strong with complexes. The binding constants for the axial ligand $\mathbf{L}$ to porphyrin $\mathbf{1 b}$ were determined in a separate experiment and $\boldsymbol{K}_{\mathbf{l b} \bullet \boldsymbol{b}}$ is the formation constant for assembly $\mathbf{1 b} \cdot \mathbf{4 b}$ under the same experimental conditions. The ratio $K_{1 b \bullet 4 b \cdot L} / K_{1 b \bullet 4 b}$ represents the ligand affinity displayed by assembly $\mathbf{1 b \bullet 4 b .}$ The results (Table 2) clearly demonstrate that in general $K_{1 b \bullet 4 b \bullet L} / K_{1 b \bullet 4 b} \leq K_{1 b \bullet L}$, which indicates that no cavity effect is operating. The binding affinity of ligands towards porphyrin is; $N$ methylimidazole > 4-methylpyridine > pyridine. In the case of covalently linked capped porphyrin, ${ }^{18}$ there is an attractive interaction between axial ligand and the $\pi$-wall of calixarene that is why the binding of ligands with covalently linked capped porphyrins was much stronger than with the free porphyrins, but the binding affinity of ligands with porphyrin calix complexes $\mathbf{1 b . 4 b}$ and $\mathbf{1 d . 4}$ is $\leq$ free porphyrins indicate minimal or no cavity effect is there.

Table 2. Binding constants, calculated for complexation of ligands with porphyrin $\mathbf{1 b}$ and assembly $\mathbf{1 b . 4 b}$

\begin{tabular}{cccc}
\hline S.No. & Ligand & $\mathrm{K}_{1 \mathrm{~b} .4 \mathrm{~b} . \mathrm{L}} / \mathrm{K}_{1 \mathrm{~b} .4 \mathrm{~b}}\left(\times 10^{2} \mathrm{M}^{-1}\right)$ & $\mathrm{K}_{1 \mathrm{~b} . \mathrm{L}}\left(\times 10^{2} \mathrm{M}^{-1}\right)$ \\
\hline 1 & $N$-methylimidazole & $32 \pm 0.6$ & $45 \pm 0.5$ \\
2 & 4-methylpyridine & $15 \pm 0.3$ & $29 \pm 0.4$ \\
3 & pyridine & $12 \pm 1.0$ & $13 \pm 0.8$ \\
\hline
\end{tabular}

$\mathrm{T}=25^{\circ} \mathrm{C}$, [porphyrin $]=[$ thiacalixarene $]=4.5 \times 10^{-6}$. Given errors are standard deviations of three measurements.

\section{Solvent and salt effect}

Ionic interaction of 25,26,27,28-tetrakis(hexyloxy)-2,8,14,20-tetrathiacalix[4]arene-5,11,17,23tetrasulfonate $\mathbf{4 b}$ with $\mathrm{Zn}$ (II)-tetrakis-( $N$-methy-4-pyridinium)porphyrin tetratosylate, $\mathbf{1 b}$ was investigated in different solvents $\left(\mathrm{H}_{2} \mathrm{O}, \mathrm{MeOH}, \mathrm{MeOH} / \mathrm{H}_{2} \mathrm{O}\right.$ 50:50, DMSO). The complexes were stable in polar solvents. Titration experiments with $\mathbf{1 b}$ and $\mathbf{4 b}$ in these solvents also gave well-defined isobestic spectral variations. The association constants in different solvents are depicted in Table 1. In $\mathrm{MeOH}$, the aggregates hold together very strongly with binding constant of $10^{8} \mathrm{M}^{-1}$ and thus $\mathrm{MeOH}$ was the best solvent for the assembly formation, possibly due to a reasonable strong template effect. In polar aprotic solvents like DMSO, the association of $\mathbf{1 b}$ and 4b was less relative to other polar solvents. This indicated a different solvation shell around the porphyrin on formation of the complex in this solvent. Complex formation in the presence of salts like $\mathrm{NaCl}$ and $\mathrm{NaClO}_{4}$ were also examined (Table 1). On titrations with $4 \mathbf{b}\left(9.96 \times 10^{-7} \mathrm{M}\right.$ to $\left.9.61 \times 10^{-6} \mathrm{M}\right)$, in the presence of $\mathrm{NaCl}$ and $\mathrm{NaClO}_{4}\left(100 \mu \mathrm{l}, 3 \times 10^{-4} \mathrm{M}\right.$, each) in $2.5 \mathrm{~mL}$ solution of $\mathbf{1 b}\left(2 \times 10^{-7} \mathrm{M}\right)$ a red shift of 7-9 $\mathrm{nm}$ was observed. Here, the data suggests that at 
lower salt concentration (resulting in a more ordered solvent shell around the ionic groups), the importance of desolvation in driving the assembly process becomes greater.

\section{pH Effect}

Cationic porphyrins self assembled in acidic or basis media to form nanowires whereas metal free porphyrins form diacid in the presence of $\mathrm{HCl}$. Thus metal free porphyrins were not suitable for $\mathrm{pH}$ effect studies. At different $\mathrm{pH}(4.0,7.0,9.0)$, titrations of metallated porphyrins $\mathbf{1 b}$ and $\mathbf{1 f}$ $\left(2.5 \mathrm{~mL}, 4.2 \times 10^{-7} \mathrm{M}\right)$ with $\mathbf{4 b}\left(4 \times 10^{-7} \mathrm{M}\right)$ were examined. Titration of $\mathbf{1 b}\left(2.5 \mathrm{~mL}, 4 \times 10^{-7} \mathrm{M}\right)$ with increasing amount of $\mathbf{4 b}$ showed a blue shift of $4 \mathrm{~nm}$ at $\mathrm{pH} 4$ (phosphate buffer) whereas a shift of $6 \mathrm{~nm}$ was observed at $\mathrm{pH}$ 9. Furthermore, at neutral $\mathrm{pH}$, the maximum red shift was 7.5 $\mathrm{nm}$ under similar conditions. Results from Table 1 indicate that neutral conditions were most suitable for ionic interaction of porphyrins and $\mathbf{4 b}$. Consistent and reproducible results were obtained with 1d.

\section{Fluorescence spectroscopy}

Fluorescence decays of cationic porphyrins in the presence of anionic TC[4]A were obtained upon excitation and emission at 425 and $650 \mathrm{~nm}$, respectively and were best analyzed with a sum of two exponentials. Solutions of porphyrins $\left(\mathbf{1 a - 1 f}, 2.0 \times 10^{-7} \mathrm{M}\right)$ in water $(2.5 \mathrm{~mL})$ were titrated with an increasing volume of $\mathbf{4 b}$ (Figure 5). On titrating 1a with increasing volumes of 4b, the peak at $651 \mathrm{~nm}$ continuously decreased with arrival of new peak at $613 \mathrm{~nm}$. A clear isobestic point was observed at $640 \mathrm{~nm}$. Similarly, in the case of $\mathbf{1 b}$ and $\mathbf{1 d}$, characteristic peak at $600 \mathrm{~nm}$ gradually decreased upon titrations of these metalloporphyrins with $\mathbf{4 b}$. It is worth mentioning here that heavy atom effect of iodide as in 5,10,15,20-tetrakis $(N$-methyl-4pyridyl)porphyrin tetraiodide quenches the fluorescence of porphyrins, reflecting the importance of counter anion in fluorescence spectroscopy. For this reason porphyrins with tosylate rather than iodide counterions were most suitable for fluorescence studies. The emission spectra and intensity of trans-meso-bis(4-pyridyl)-diphenylporphyrin $\mathbf{1 e}$ and mono(4-pyridyl)triphenylporphyrin 1f remain unchanged upon addition of $\mathbf{4 b}$, indicating no interaction between 1e, 1f and 4b. Binding constants calculated by fluorescence spectroscopy were in good agreement with those calculated by UV-vis spectroscopy (Table 1, entry 1 to 7). 


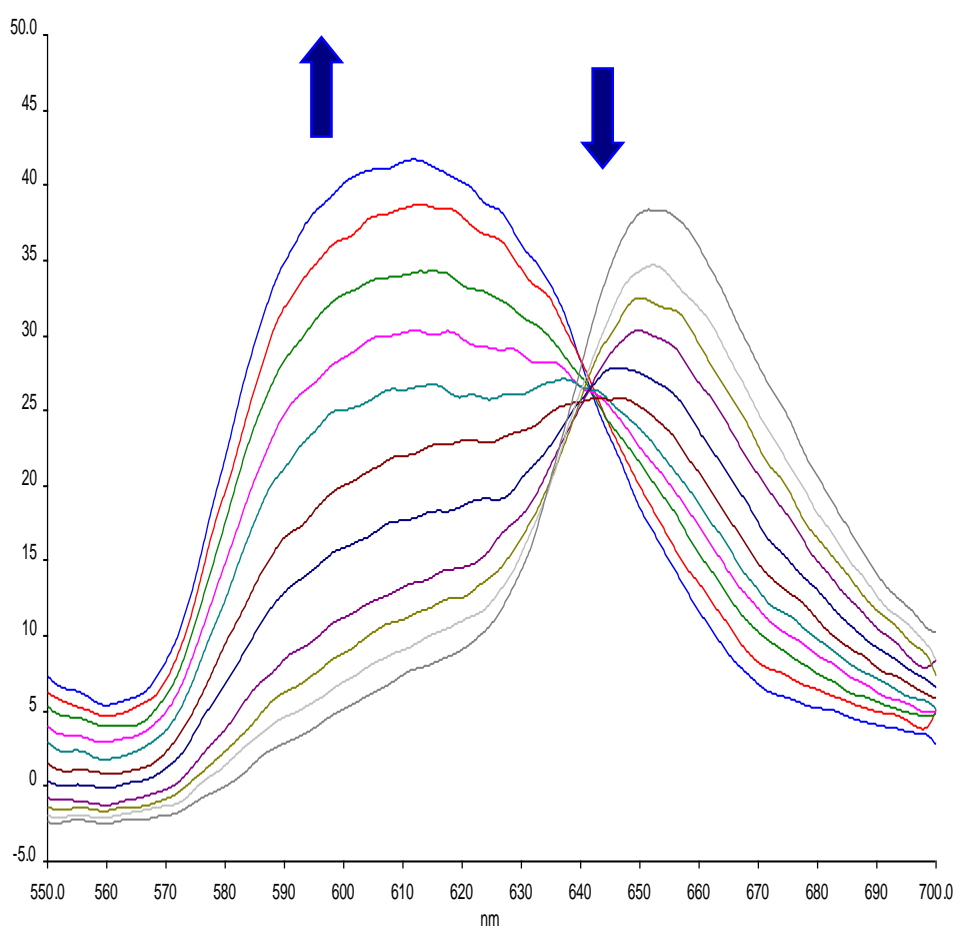

Figure 5. Fluorescence spectra of $\mathbf{1 c}\left(2 \times 10^{-7} \mathrm{M}\right)$ upon titration with $\mathbf{4 b}\left(0.2 \times 10^{-7} \mathrm{M}\right.$ to $4.8 \times$ $\left.10^{-7} \mathrm{M}\right)$.

\section{${ }^{1}$ H NMR spectroscopy}

To further shed light on the ionic interaction, ${ }^{1} \mathrm{H}$ NMR titrations were carried out at $298 \mathrm{~K}$. The ${ }^{1} \mathrm{H}$ NMR spectra of $\mathbf{1 b}$ in $\mathrm{D}_{2} \mathrm{O}\left(2 \times 10^{-4} \mathrm{M}\right)$ clearly showed four doublets at $\delta 9.14\left(\mathrm{H}_{\mathrm{o}-\mathrm{py}}\right), 8.65$ $\left(\mathrm{H}_{\mathrm{m}-\mathrm{py}}\right), 7.53\left(\mathrm{H}_{\mathrm{o}-\text { tosyl }}\right)$ and $7.00 \mathrm{ppm}\left(\mathrm{H}_{\mathrm{m} \text {-tosyl }}\right)$, respectively. In addition, $\beta$-pyrrolic protons appeared at $\delta 8.80 \mathrm{ppm}\left(\mathrm{H}_{\beta \text {-pyr }}\right)$. The changes in the ${ }^{1} \mathrm{H}$ NMR spectra of $\mathbf{1 b}$ upon addition of aliquots of $4 \mathbf{b}\left(0.67 \times 10^{-4} \mathrm{M}\right)$ with $10 \mathrm{~min}$ intervals is depicted in Figure 6 . The 1:1 complex showed that $o$-pyridyl protons $\left(\mathrm{H}_{\mathrm{o}-\mathrm{py}}\right)$ shifted upfield from $\delta 9.14$ to 8.49 while $m$-pyridyl protons $\left(\mathrm{H}_{\mathrm{m}-\mathrm{py}}\right)$ shifted from $\delta 8.65$ to $8.21 \mathrm{ppm}$. The largest shifts were observed for $o$-pyridyl $(\delta \Delta 0.65)$ which suggests that these protons are located in close proximity to the sulfonate group of $\mathbf{4 b}$. Upon gradual addition of $\mathbf{4 b}$, the pyridyl doublets, $\mathrm{H}_{\mathrm{o}-\mathrm{py}}$ and $\mathrm{H}_{\mathrm{m}-\mathrm{py}}$ changed into singlet with considerable upfield shifting while the signals due to $\beta$-protons $\left(\mathrm{H}_{\beta \text {-pyr }}\right)$ and tosylate protons $\left(\mathrm{H}_{\mathrm{o}}\right.$ tosyl and $\left.\mathrm{H}_{\mathrm{m} \text {-tosyl }}\right)$ remain essentially unchanged and appeared as singlet. The phenyl protons $\left(\mathrm{H}_{\text {phe }}\right)$ of $\mathbf{4 b}$ at $\delta 7.2$ also shifted upfield to $\delta 6.9$ in the 1:1 complex. Surprisingly, when excess of $\mathbf{4 b}$ (2 $\times 10^{-5} \mathrm{M}$ ) was added to the solution of $\mathbf{1 b}$, the signals of $\mathrm{H}_{\mathrm{m}-\mathrm{py}}, \mathrm{H}_{\mathrm{o} \text {-tosyl }}$ and $\mathrm{H}_{\beta \text {-pyr }}$ disappeared. 


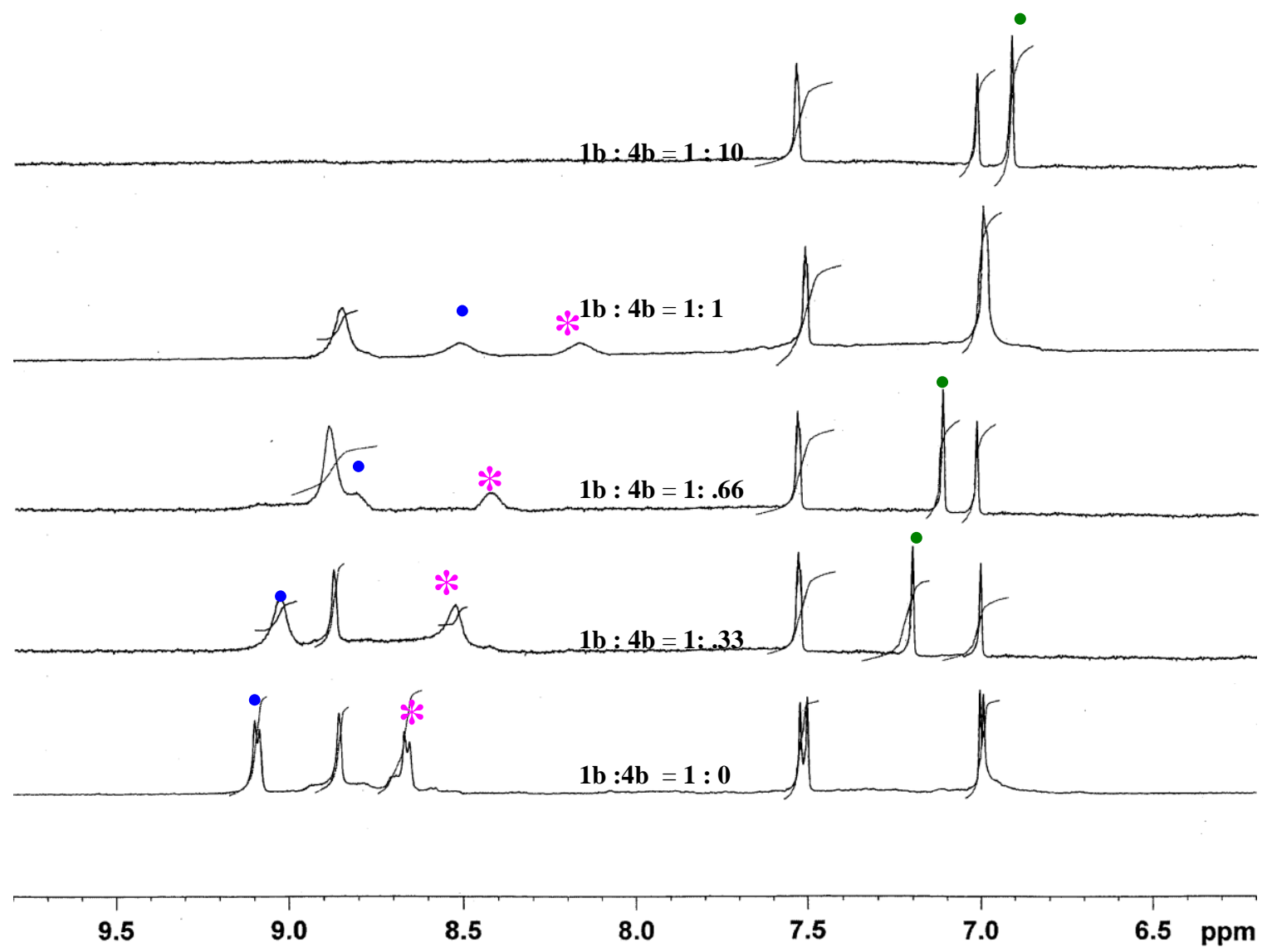

Figure 6. Selected region of ${ }^{1} \mathrm{H}$ NMR spectra of $\mathbf{1 b}\left(2 \times 10^{-4} \mathrm{M}\right)$ in $\mathrm{D}_{2} \mathrm{O}$ upon addition of $\mathbf{4 b}$ at $298 \mathrm{~K}$. The ortho pyridyl proton, meta pyridyl protons and aromatic protons of TCA are designated as blue, magenta and green colors.

\section{ESI-MS spectrometry}

ESI-MS has been used as a powerful tool which allows the fast, unambiguous and sensitive simultaneous detection and relative stability approximation of supramolecular assemblies in mixtures. ${ }^{21}$ Under the appropriate experimental conditions, ESI-MS allows the detection of intact non-covalent complexes. ESI-MS spectra of $\mathrm{Zn}(\mathrm{II})-\mathrm{N}$-methyltetrakis-(4-pyridyl)porphyrin tetratosylate $\mathbf{1 b}\left(2.0 \times 10^{-7} \quad \mathrm{M}\right)$ and 25,26,27,28-tetrakis-(hexyloxy)-2,8,14,20tetrathiacalix[4]arene-5,11,17,23-tetrasulfonate $\mathbf{4 b}\left(2.0 \times 10^{-7} \mathrm{M}\right)$ gave a peak at 1911.0143 at low cone voltage $(30 \mathrm{~V})$ which was assigned for singly charged $[\mathbf{1 b}+\mathbf{4 b}-\mathbf{4 t o s y}-\mathbf{3 N a}]^{+}$species and supported the formation of 1:1complex (Figure 7). Peak at 740.2360 [1b-4Tosy $^{+4}$ with $100 \%$ intensity was recognized due to $\mathrm{Zn}$-Por. On the contrary, at high cone voltage (70V), the methyl groups successively removed from porphyrin and two new peaks at 710.1886 (1b-2CH34Tosy $)^{+2}$ and 695.1650 (1)-3CH3-4Tosyl. $)^{+1}$ were observed. Formation of ternary complex of Zn-porphyrin-thiacalix[4] arene $\mathbf{1 b . 4 b}$ and pyridine in 1:1:1 ratio was also confirmed by ESI-MS spectroscopy. Furthermore, on addition of pyridine $\left(2.0 \times 10^{-7} \mathrm{M}\right)$ to the complex $\mathbf{1 b . 4 b}$, some 
additional peaks were observed at 2014.4295 and 1991.4369 due to $[\mathbf{1 b}+\mathbf{4 b}+\mathbf{L}-\mathbf{4 T o s y}-2 \mathbf{N a}]^{+2}$ and $[\mathbf{1 b}+\mathbf{4 b}+\mathbf{L}-\mathbf{4 T o s y}-3 \mathrm{Na}]^{+}$, respectively.

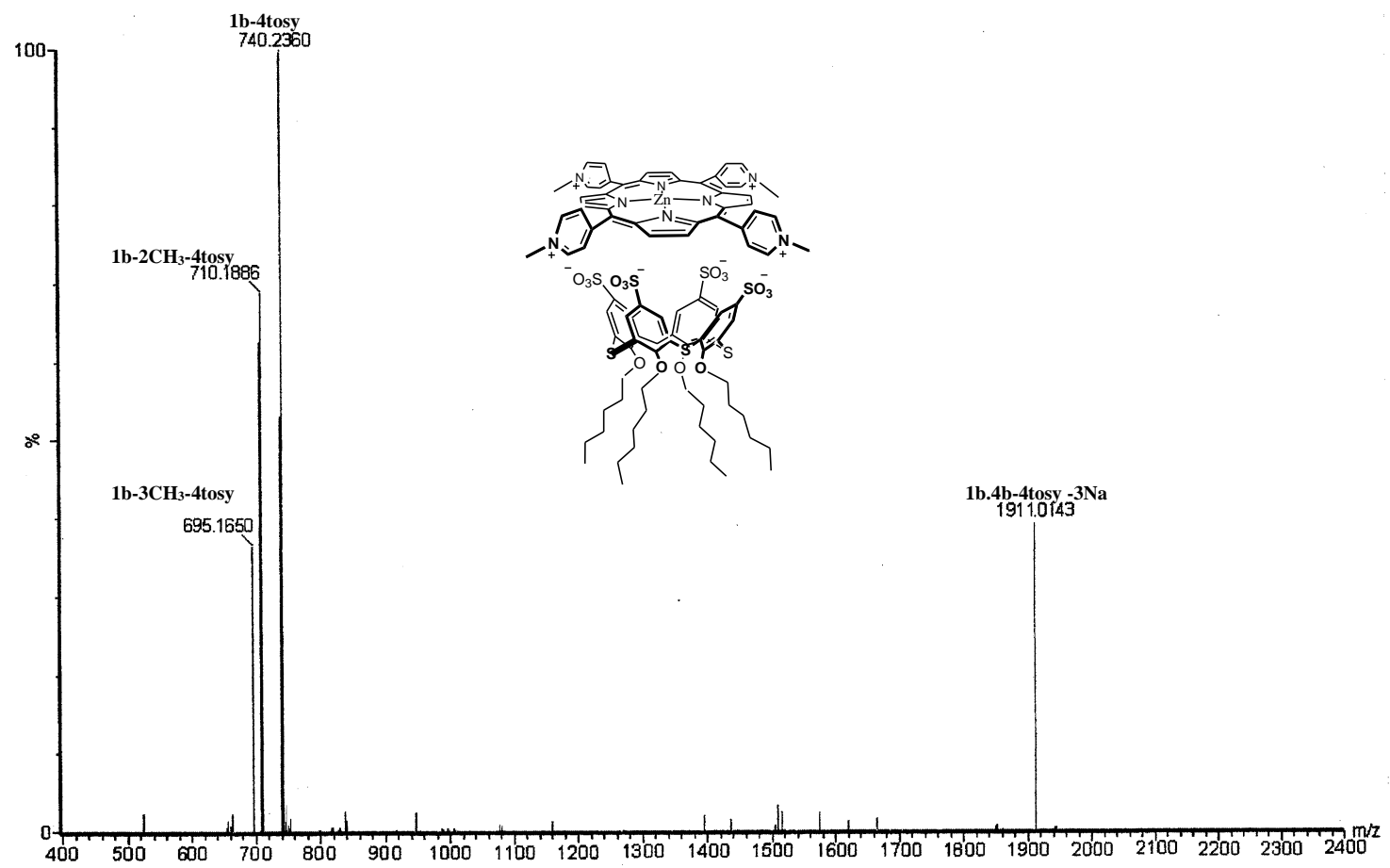

Figure 7. ESI-MS spectra of the $1: 1$ complex $\mathbf{1 b . 4 b}\left(0.2 \times 10^{-7} \mathrm{M}\right)$.

\section{Conclusions}

We have introduced a novel class of supramolecular self-assembly driven by ionic interactions between tetracationic porphyrins and tetraanionic thiacalix[4]arene derivatives in polar solvents. A detailed spectroscopic analysis revealed the formation of 1:1 ionic complex between two investigated derivatives. The fashioned, 1:1 complexes were further utilized in the formation of 1:1:1 ternary complex by axial coordination of ligands. Spectroscopic findings indicate that anionic TC[4]As strongly bind with cationic porphyrins under different conditions than classical C[4]As which had previously proved successful for ionic interactions. Higher flexibility of metal free porphyrins promote them to strongly bind with anionic thiacalix[4]arene than metallated porphyrins.

We believe that present studies based on ionic interactions will be a welcome addition to TC[4]A chemistry and can be further extended to more complicated supramolecular systems for encapsulation of different guest molecules or in the formation of nanocapsules under physiological conditions. 


\section{Experimental Section}

General. The infrared spectra (IR) were recorded on Perkin Elmer FT-1710 spectrophotometer. ${ }^{1} \mathrm{H}$ and ${ }^{13} \mathrm{C}$ NMR spectra were recorded on Bruker Avance 300 spectrophotometer at 300 and 75 $\mathrm{MHz}$, respectively. ESI-MS spectra were recorded on KC 455-TOF mass spectrometer (Micromass, Manchester, UK). UV-vis spectra were recorded on Perkin Elmer Lambda-35 spectrophotometer. Zinc(II) meso-tetrakis( $N$-alkylpyridinium-3/4-yl)-porphyrins 1a-f were prepared in three steps by condensation of pyridine carboxyldehydes with pyrrole in a refluxing propionic acid followed by alkylation with methyl toluenesulfonate (100 equiv) and subsequent zinc insertion in an overall yield of $14-18 \%$ following literature procedures ${ }^{22}$ and $\mathbf{1 g}$ was prepared by Lindsey method by using 4 -( $N, N$-dimethylamino)carboxyldehyde instead of pyridine carboxaldehydes.

Synthesis of 25,26,27,28-tetrahydroxy-2,8,14,20-tetrathia-5,11,17,23-tetra(tertbutyl)calix[4]arene (2). The mixture of p-tert-butylphenol (64.5 g, $0.43 \mathrm{~mol})$, elemental sulfur, $\mathrm{S}_{8}(27.5 \mathrm{~g}, 0.86 \mathrm{~mol})$, and $\mathrm{NaOH}(8.86 \mathrm{~g}, 0.215 \mathrm{~mol})$ in tetraethylene glycol dimethyl ether (19 $\mathrm{mL}$ ) was stirred under nitrogen. The stirred mixture was heated gradually to $230{ }^{\circ} \mathrm{C}$ over a period of $4 \mathrm{~h}$ and kept at this temperature for $3 \mathrm{~h}$ with concomitant removal of the evolving hydrogen sulfide with a slow stream of nitrogen. The resulting dark red product was cooled to ambient temperature and diluted with toluene and ether, and then $1 / 2 \mathrm{M}$ aq. sulfuric acid solution was added with stirring to give a suspension. The precipitate was collected by filtration, recrystallized from chloroform and dried in vacuo $\left(100{ }^{\circ} \mathrm{C}, 4 \mathrm{~h}\right)$ to get pure sample of 25,26,27,28tetrahydroxy-2,8,14,20-tetrathiacalix[4]arene. The mother liquor of the recrystallization was concentrated in vacuo, and chromatography of the residue on silica gel (Hexane: $\mathrm{CHCI}_{3}, 4: 6$, v/v) afforded second crop of thiacalix[4]arene. Colorless prisms (from $\mathrm{CHCl}_{3}$ ); Yield: $52 \%$ (after crystallization); IR (KBr, cm $\left.{ }^{-1}\right): 3324,2962 ;{ }^{1} \mathrm{H} \mathrm{NMR}\left(300 \mathrm{MHz}, 25{ }^{\circ} \mathrm{C}, \mathrm{CDCl}_{3}\right): 1.24$ (s, $\mathrm{t}-\mathrm{Bu}, 36 \mathrm{H}), 7.68\left(\mathrm{~s}, \mathrm{CH}_{\mathrm{Ar}} 8 \mathrm{H}\right)$, and $9.58(\mathrm{~s}, \mathrm{OH}, 4 \mathrm{H}) ;{ }^{13} \mathrm{C} \mathrm{NMR}\left(75 \mathrm{MHz}, 25{ }^{\circ} \mathrm{C}, \mathrm{CDCl}_{3}\right): 31.4$ $\left[\mathrm{C}\left(\underline{\mathrm{CH}}_{3}\right)_{3}\right], 34.3\left[\underline{\mathrm{C}}\left(\mathrm{CH}_{3}\right)_{3}\right]$, and 121.1 ( $\left.\underline{\mathrm{Ar}}_{\text {meta }}\right), 135.9$ ( $\left.\underline{\mathrm{Ar}}_{\text {ortho }}\right), 145.7$ (t-BuC $), 155.6(\underline{\mathrm{C}}-\mathrm{OH})$; HRMS (ESI-MS +ve mode) for $\mathrm{C}_{40} \mathrm{H}_{48} \mathrm{O}_{4} \mathrm{~S}_{4} \mathrm{Na}[\mathrm{M}+\mathrm{Na}]^{+}$: Calcd: 743.2333, Found: 743.2322.

Synthesis of 25,26,27,28-tetrakis-(butyloxy)-2,8,14,20-tetrathia-5,11,17,23-tetra(tertbutyl)calix[4]arene (3a). The mixture of 25,26,27,28-tetrahydroxy-2,8,14,20tetrathiacalix[4]arene 2 (1.056 g, $1 \mathrm{mmol})$, sodium hydride $(480 \mathrm{mg}, 20 \mathrm{mmol})$ and n-butyl bromide (3.3 g, $20 \mathrm{mmol})$ was stirred under reflux in acetone $(20 \mathrm{~mL})$ for $2 \mathrm{~d}$. The reaction mixture was cooled to room temperature, carefully neutralized with diluted hydrochloric acid and extracted with dichloromethane. The organic layer was washed with water, dried $\left(\mathrm{MgSO}_{4}\right)$ and evaporated to dryness. The semi-solid residue was purified by column chromatography on silica gel using petroleum ether/chloroform (gradient from 10:1 to 5:1, v/v) as eluent to get 3a as white solid. Yield: $1.16 \mathrm{~g}$ (55 \%); IR $\left(\mathrm{KBr}, \mathrm{cm}^{-1}\right)$ : 3025, 2967, 1437, 1026, 757; ${ }^{1} \mathrm{H}$ NMR (300 $\left.\mathrm{MHz}, 25{ }^{\circ} \mathrm{C}, \mathrm{CDCl}_{3}\right): 7.30$ (s, 8H, Ar), 3.80 (t, 8H, $\left.-\mathrm{OCH}_{2}\right), 1.01-1.13\left(\mathrm{~m}, 8 \mathrm{H},-\mathrm{CH}_{2}\right), 0.99-1.08$ $\left(\mathrm{m}, 8 \mathrm{H},-\mathrm{CH}_{2}\right), 1.27(\mathrm{~s}, 36 \mathrm{H}, \mathrm{t}-\mathrm{Bu}), 0.92\left(\mathrm{t}, 12 \mathrm{H},-\mathrm{CH}_{3}\right) ;{ }^{13} \mathrm{C} \mathrm{NMR}\left(75 \mathrm{MHz}, 25{ }^{\circ} \mathrm{C}, \mathrm{CDCl}_{3}\right)$ : 
$13.29\left(\mathrm{CH}_{2} \underline{\mathrm{CH}}_{3}\right), 18.73\left(\underline{\mathrm{CH}_{2}} \mathrm{CH}_{3}\right), 30.88\left(\underline{\mathrm{CH}_{2}} \mathrm{CH}_{2} \mathrm{CH}_{3}\right), 31.40\left[\underline{\mathrm{C}}\left(\mathrm{CH}_{3}\right)_{3}\right], 34.00\left[\mathrm{C}\left(\underline{\mathrm{CH}}_{3}\right)_{3}\right]$, $67.90\left(\mathrm{OCH}_{2}\right), 126.86\left(\mathrm{Ar}_{\text {meta }}\right), 127.53\left(\mathrm{Ar}_{\text {ortho }}\right), 144.80\left[\underline{\mathrm{C}}-\mathrm{C}\left(\mathrm{CH}_{3}\right)_{3}\right], 156.57\left(\underline{\mathrm{C}}-\mathrm{OC}_{4} \mathrm{H}_{9}\right)$; ESIMS: for $\mathrm{C}_{56} \mathrm{H}_{80} \mathrm{O}_{4} \mathrm{~S}_{4} \mathrm{Na}(\mathrm{M}+\mathrm{Na})^{+}$: Calcd: 967.5832, Found: 967.5845 .

Synthesis of 25,26,27,28-tetrakis-(hexyloxy)-2,8,14,20-tetrathia-5,11,17,23-tetra(tertbutyl)calix[4]arene (3b). The 25,26,27,28-tetrakis(hexyloxy)-2,8,14,20-tetrathia-5,11,17,23tetra(tert-butyl) calix[4]arene has been synthesized as described above except hexyl bromide was used. White solid; Yield: $60 \%$; Rf: 0.45 (petroleum ether: chloroform, 7:3); IR ( $\left.\mathrm{KBr}, \mathrm{cm}^{-1}\right)$ : 3030, 2970, 1450, 1070, 753; ${ }^{1} \mathrm{H}$ NMR (300 MHz, $25{ }^{\circ} \mathrm{C}, \mathrm{CDCl}_{3}$ ): 7.19 (s, Ar, 8H), 3.74 (t, O$\left.\mathrm{CH}_{2}, 8 \mathrm{H}\right), 1.93\left(\mathrm{~m}, \mathrm{CH}_{2}, 8 \mathrm{H}\right), 1.48\left(\mathrm{~m}, \mathrm{CH}_{2}, 8 \mathrm{H}\right), 1.19$ (s, t-Bu, 36H), $1.06\left(\mathrm{~m}, \mathrm{CH}_{2}, 8 \mathrm{H}\right), 0.95$ $\left(\mathrm{m}, \mathrm{CH}_{2}, 8 \mathrm{H}\right), 0.78\left(\mathrm{t}, \mathrm{CH}_{3}, 12 \mathrm{H}\right) ;{ }^{13} \mathrm{C} \mathrm{NMR}\left(75 \mathrm{MHz}, 25{ }^{\circ} \mathrm{C}, \mathrm{CDCl}_{3}\right): 13.73\left(\mathrm{CH}_{2} \underline{\mathrm{CH}}_{3}\right), 14.19$ $\left(\underline{\mathrm{CH}_{2}} \mathrm{CH}_{3}\right), 15.79\left(\underline{\mathrm{CH}}_{2} \mathrm{CH}_{2} \mathrm{CH}_{3}\right), 16.31\left(\underline{\mathrm{CH}_{2}} \mathrm{CH}_{2} \mathrm{CH}_{2} \mathrm{CH}_{3}\right), 18.96\left(\underline{\mathrm{CH}_{2}} \mathrm{CH}_{2} \mathrm{CH}_{2} \mathrm{CH}_{2} \mathrm{CH}_{3}\right), 31.32$ $\left[\underline{\mathrm{C}}\left(\mathrm{CH}_{3}\right)_{3}\right], 34.19\left[\mathrm{C}\left(\underline{\mathrm{CH}_{3}}\right)_{3}\right], 68.34\left(\mathrm{OCH}_{2}\right), 127.30\left(\mathrm{Ar}_{\text {meta }}\right), 128.42\left(\mathrm{Ar}_{\text {ortho}}\right), 145.24$ [드$\left.\mathrm{C}\left(\mathrm{CH}_{3}\right)_{3}\right], 156.53\left(\underline{\mathrm{C}}-\mathrm{OC}_{6} \mathrm{H}_{13}\right)$; HRMS (ESI-MS +ve mode) for $\mathrm{C}_{64} \mathrm{H}_{96} \mathrm{Na}_{3} \mathrm{O}_{4} \mathrm{~S}_{4} \mathrm{Na}[\mathrm{M}+\mathrm{Na}]^{+}$: Calcd: 1079.6089, Found: 1079.6071.

Synthesis of 25,26,27,28-tetrakis-(butyloxy)-2,8,14,20-tetrathiacalix[4]arene-5,11,17,23tetrasulfonate (4a). The 25,26,27,28-tetrabutyloxy-2,8,14,20-tetrathiacalix[4]arene 14a (1g, $0.95 \mathrm{mmol}$ ) was taken in $100 \mathrm{~mL}$ round bottom flask and conc. sulfuric acid (30 $\mathrm{mL})$ was added. The reaction mixture was stirred for $1 \mathrm{~d}$ at $70-80^{\circ} \mathrm{C}$. The progress of the reaction was monitored by taken an aliquot of reaction mixture and adding it to water. The reaction was considered complete when no water insoluble material was detected. The reaction mixture was then added to water $(200 \mathrm{~mL})$ and neutralized with $\mathrm{BaCO}_{3}$. The reaction mixture was filtered and $\mathrm{pH}$ of the filtrate was adjusted to $7.5-8.0$ with $\mathrm{Na}_{2} \mathrm{CO}_{3}$ solution. The solution was filtered again and residue was washed with water. Combined filtrate was distilled under reduced pressure. The residue, obtained was dissolved in water $(20 \mathrm{~mL})$ and precipitated by addition of ethanol to get white solid of 25,26,27,28-tetrabutyloxy-2,8,14,20-tetrathiacalix[4]arene-5,11,17,23tetrasulfonate 4a. Yield: $267 \mathrm{mg}(26 \%)$; IR $\left(\mathrm{KBr}, \mathrm{cm}^{-1}\right)$ : 3510- 3150 (br), 3065, 2982, 1453, 1192, 1057, 791; ${ }^{1} \mathrm{H}$ NMR (300 MHz, 25 ${ }^{\circ} \mathrm{C}, \mathrm{D}_{2} \mathrm{O}$ ): 7.31 (s, 8H, Ar), 3.79 (t, 8H, -OCH $), 1.52$ $\left(\mathrm{m}, 8 \mathrm{H},-\mathrm{CH}_{2}\right), 1.32\left(\mathrm{~m}, 8 \mathrm{H},-\mathrm{CH}_{2}\right), 0.87\left(\mathrm{t}, 12 \mathrm{H}, \mathrm{CH}_{3}\right) ;{ }^{13} \mathrm{C} \mathrm{NMR}\left(75 \mathrm{MHz}, 25^{\circ} \mathrm{C}, \mathrm{D}_{2} \mathrm{O}\right): 13.45$ $\left(\mathrm{CH}_{2} \underline{\mathrm{CH}_{3}}\right), 17.68\left(\underline{\mathrm{CH}_{2}} \mathrm{CH}_{3}\right), 23.76\left(\underline{\mathrm{CH}_{2}} \mathrm{CH}_{2} \mathrm{CH}_{3}\right), 68.78\left(\underline{\mathrm{OCH}_{2}}\right), 127.68$ (Ar $\left.{ }_{\text {meta }}\right), 128.32$

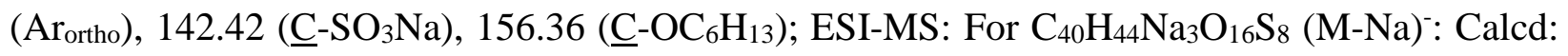
1105.4634, Found: 1105.4628.

Synthesis of 25,26,27,28-tetrakis-(hexyloxy)-2,8,14,20-tetrathiacalix[4]arene-5,11,17,23tetrasulfonate (4b). The 25,26,27,28-tetrakis(hexyloxy)-2,8,14,20-tetrathia-calix[4]arene5,11,17,23-tetrasulfonate $\mathbf{4 b}$ has been synthesized by the sulfonation of 25,26,27,28tetrakis(hexyloxy)-2,8,14,20-tetrathiacalix[4]arene-5,11,17,23-tetrasulfonate $(1.03 \mathrm{~g}, 1 \mathrm{mmol})$ as reported for 4a. White solid; yield: $358 \mathrm{mg}, 30 \%$; IR (KBr, $\left.\mathrm{cm}^{-1}\right)$ : 3515- 3100 (br), 3070, 2980, 1450, 1130, 1038, 1058, 792; ${ }^{1} \mathrm{H}$ NMR (300 MHz, 25 $\left.{ }^{\circ} \mathrm{C}, \mathrm{D}_{2} \mathrm{O}\right): 7.14$ (s, Ar, 8H), 3.9 (t ,O-CH , $8 \mathrm{H}), 1.25\left(\mathrm{~m}, \mathrm{CH}_{2}, 8 \mathrm{H}\right), 1.48\left(\mathrm{~m}, \mathrm{CH}_{2}, 8 \mathrm{H}\right), 1.1\left(\mathrm{~m}, \mathrm{CH}_{2}, 8 \mathrm{H}\right), 0.97\left(\mathrm{~m}, \mathrm{CH}_{2}, 8 \mathrm{H}\right), 0.77\left(\mathrm{t}, \mathrm{CH}_{3}\right.$, $12 \mathrm{H}) ;{ }^{13} \mathrm{C} \mathrm{NMR}\left(75 \mathrm{MHz}, 25^{\circ} \mathrm{C}, \mathrm{D}_{2} \mathrm{O}\right): 14.24\left(\mathrm{CH}_{2} \underline{\mathrm{CH}_{3}}\right), 14.90\left(\underline{\mathrm{CH}_{2}} \mathrm{CH}_{3}\right), 15.82\left(\underline{\mathrm{CH}_{2}} \mathrm{CH}_{2} \mathrm{CH}_{3}\right)$, $16.70\left(\underline{\mathrm{CH}_{2}} \mathrm{CH}_{2} \mathrm{CH}_{2} \mathrm{CH}_{3}\right), 19.60\left(\underline{\mathrm{CH}_{2}} \mathrm{CH}_{2} \mathrm{CH}_{2} \mathrm{CH}_{2} \mathrm{CH}_{3}\right), 69.00\left(\mathrm{OCH}_{2}\right), 127.74$ (Ar $\left.\mathrm{Arta}_{\text {met }}\right), 128.74$ 
$\left(\mathrm{Ar}_{\text {ortho}}\right), \quad 146.73 \quad\left(\underline{\mathrm{C}}-\mathrm{SO}_{3} \mathrm{Na}\right), \quad 157.20 \quad\left(\underline{\mathrm{C}}-\mathrm{OC}_{6} \mathrm{H}_{13}\right) ; \quad \mathrm{HRMS} \quad(\mathrm{ESI}-\mathrm{MS} \quad$-ve mode) for $\mathrm{C}_{48} \mathrm{H}_{60} \mathrm{Na}_{3} \mathrm{O}_{16} \mathrm{~S}_{8} .[\mathrm{M}-\mathrm{Na}]^{-}:$Calcd: 1217.1340 , Found: 1217.1351.

\section{Acknowledgements}

The authors are thankful to Council of Scientific and Industrial Research (CSIR), Department of Science and Technology (DST) and University of Delhi for financial assistance.

\section{References}

1. (a) Fujita, M.; Umemoto, K.; Yoshizawa, M.; Fujita, N.; Kusukawa, T.; Biradha, K. Chem.Commun. 2001, 509. (b) Rebek, J., Jr. Angew. Chem., Int. Ed. 2005, 44, 2068. (c) Dalgarno, S. J.; Power, N. P.; Atwood, J. L. Coord. Chem. Rev. 2008, 252, 825. (d) Zhang, Y.-Q.; Zeng, J.-P.; Zhu, Q.-J.; Xue, S.-F.; Tao, Z. J. Mol. Structure 2009, 929, 167. (e) Ajami, D.; Hou, J.-L.; Dale, T. J.; Barrett, E.; Rebek, J., Jr. PNAS 2009, 106, 10430.

2. (a) Corbellini, F.; Knegtel, R. M. A.; Grootenhuis, P. D. J.; Crego-Calama, M.; Reinhoudt, D. N. Chem. Eur. J. 2005, 11, 298. (b) Corbellini, F.; van Leeuwen, F. W. B.; Beijleveld, H.; Kooijman, H.; Spek, A. L.; Verboom, W.; Crego-Calama, M.; Reinhoudt, D. N. New. J. Chem. 2005, 29, 243. (c) Corbellini, F.; Fiammengo, R.; Timmerman, P.; Crego-Calama, M.; Versluis, K.; Heck, A. J. R.; Luyten, I.; Reinhoudt, D. N. J. Am. Chem. Soc. 2002, 124, 6569.

3. (a) Lützen, A. Angew. Chem., Int. Ed. 2005, 44, 1000. (b) Chen, J.; Rebek, J. Jr. Org. Lett. 2002, 4, 327. (c) Merlau, M. L.; Del Pilar Mejia, M.; Nguyen, S. T.; Hupp, J. T. Angew. Chem., Int. Ed. 2001, 40, 4239. (d) Yoshizawa, M.; Takeyama, Y.; Okano, T.; Fujita, M. J. Am. Chem. Soc. 2003, 125, 3243. (e) Ziegler, M.; Brumaghim, J. L.; Raymond, K. N. Angew. Chem., Int. Ed. 2000, 39, 4119-4121.

4. (a) Yamanaka, M.; Shivanyuk, A.; Rebek, J., Jr. J. Am. Chem. Soc. 2004, 126, 2939. (b) Rebek, J., Jr. Acc. Chem. Res. 1999, 32, 278. (c) Rebek, J., Jr. Chem. Commun. $2000,637$. (d) Baldini, L.; Sansone, F.; Faimani, G.; Massera, C.; Casnati, A.; Ungaro, R. Eur. J. Org. Chem. 2008, 869. (e) Moon, C.; Brunklaus, G.; Sebastiani, D.; Rudzevich, Y.; Bhömer, V.; Spiess, H. W. Phys. Chem. Chem. Phys. 2009, 11, 9241. (b) Liao, W.; Bi, Y.; Gao, S.; Li, D.; Zhang, H.; Dronskowski, R. Eur. J. Inorg. Chem. 2008, 2959.

5. (a) Kryschenko, Y. K.; Seidel, S. R.; Muddiman, D. C.; Nepomuceno, A. I.; Stang, P. J. J. Am. Chem. Soc. 2003, 125, 9647. (b) Jacopozzi, P.; Dalcanale, E. Angew. Chem., Int. Ed. 1997, 36, 613. (c) Radhakrishnan, U.; Schweiger, M.; Stang, P. J. Org. Lett. 2001, 3, 3141. (d) Leung, D. H.; Fiedler, D.; Bergman, R. G.; Raymond, K. N. Angew. Chem., Int. Ed. 2004, 43, 963. 
6. (a) Grawe, T.; Schrader, T.; Gurrath, M.; Kraft, A.; Osterod, F. Org. Lett. 2000, 2, 29. (b) Sasine, J. S.; Brewster, R. E.; Caran, K. L.; Bentley, A. M.; Shuker, S. B. Org. Lett. 2006, 8, 2913.

7. (a) Korner, S. K.; Tucci, F. C.; Rudkevich, D. M.; Heinz, T.; Rebek, J., Jr. Chem. Eur. J. 2000, 6, 187. (b) Shivanyuk, A.; Rebek, J., Jr. Chem. Commun. 2001, 2424. (c) Fochi, F.; Jacopozzi, P.; Wegelius, E.; Rissanen, K.; Cozzini, P.; Marastoni, E.; Fisicaro, E.; Manini, P.; Fokkens, R.; Dalcanale, E. J. Am. Chem. Soc. 2001, 123, 7539. (d) Thondorf, I.; Rudzevich, Y. ; Rudzevich, V.; Böhmer, V. Org. Biomol. Chem., 2007, 5, 2775. (e) Liu, Y. ; Guo, D.-S.; Zhang, H.-Y.; Ding, F.; Chen, K.; Song, H.-B. Chem. Eur. J. 2007, 13, 466 (f) Martin, A. D.; Sobolev, A. N.; Spackman, M. A.; Raston, C. L. Crystal Growth \& Design, 2009, 9, 3759. (g) Szumna, A. Chem. Eur. J. 2009, 15, 12381. (h) Park, S. J.; Yamaguchi, K.; Hong, J.-I. Bull. Korean Chem. Soc. 2008, 29, 205.

8. (a) Parson, W. W.; Warshel, A. J. Am. Chem. Soc. 1987, 109, 6152. (b) Armitage, B.; Klekotka, P. A.; Oblinger, E.; O’Brien, D. F. J. Am. Chem. Soc. 1993, 115, 7920. (c) Santiago, Patricia S.; Gandini, Shirley C. M.; Moreira, Leonardo M.; Tabak, Marcel. J. Porphyrins Phthalocyanines 2008, 12, 942 (d) Pavel, K.; Kamil, L.; Pavel, J.; Ota, F.; Irena, M.; Jan, S.; Svatopluk, C.; Martin, H.; Ladislav, K. J. Nanosci. Nanotechnol. 2009, 9, 5795.

9. (a) Anantha, N. V.; Azam, N.; Sheardy, R. D. Biochemistry 1998, 37, 2709. (b) Han, H.; Langley, D. R.; Rangan, A.; Hurdley, L. H. J. Am. Chem. Soc. 2001, 123, 8902. (c) Sun, D.; Thompson, B.; Cathers, B. E.; Salazar, M.; Kerwin, S. M.; Trent, J. O.; Jenkins, T. C.; Neidle, S.; Hurdey, L. H. J. Med. Chem. 1997, 40, 2113. (d) Mita, H.; Ohyama, T.; Tanaka, Y.; Yamamoto, Y. Biochemistry, 2006, 45, 6765. (e) Jia, G.; Feng, Z.; Wei, C.; Zhou, J.; Wang, X.; Li, C. J. Phys. Chem. B 2009, 113, 16237.

10. (a) Talanova, G. G.; Elkarim, N. S. A.; Talanov, V. S.; Bartsch, R. A. Anal. Chem. 1999, 71, 3106. (b) Ying-Wei, Y.; Heng-Yi, Z.; Yu, L. Supramol. Chem. 2008, 20, 731. (c) Nikitin, K.; Müller-Bunz, H. New J. Chem. 2009, 33, 2472. (d) Ferreirós-Martí nez, R.; EstebanGómez, D.; Blas, de A.; Platas-Iglesias, C.; Rodríguez-Blas, T. Inorg. Chem. 2009, 48, 11821. (e) Jóźwiak, M.; Madej, L. J. Solution Chem. 2009, 38, 1635.

11. (a) Lee, S. H.; Kim, J. Y.; Ko, J.; Lee, J. Y.; Kim, J. S. J. Org. Chem. 2004, 69, 2902. (b) Pospíšil, L.; Hromadová, M.; Gál, M.; Bulíčková, J.; Sokolová, R.; Filippone, S.; Yang, J.; Guan, Z.; Rassat, A.; Zhang, Y. Carbon 2010, 48, 153.

12. (a) Lhoták, P.; Dudič, M.; Stibor, I.; Petř́íčková, H.; Sýkora, J.; Hodacova, J. Chem.Commun. 2001, 731-732. (b) Kundrat, O.; Dvorakova, H.; Cisarova, I.; Pojarova, M.; Lhotak, P. Org. Lett. 2009, 11, 4188. (b) Kundrat, O.; Cisarova, I.; Böhm, S.; Pojarova, M.; Lhotak, P. J. Org. Chem. 2009, 74, 4592. (c) Iki, N. J Incl Phenom Macrocycl Chem 2009, 64, 1 and references there in. (d) Buccella, D.; Parkin, G. Chem. Commun., 2009, 289.

13. Dudič, M.; Lhoták, P.; Stibor, I.; Lang, K.; Prošková, P. Org. Lett. 2003, 5, 149.

14. Dudic, M.; Lhoták, P.; Stibor, I.; Dvoráková, H.; Lang, K. Tetrahedron 2002, 58, 5475. 
15. (a) Dudič, M.; Lhoták, P.; Petříčková, H.; Stibor, I.; Lang, K.; Sýkora, J. Tetrahedron 2003, 59, 2409. (b) Kundrát, O.; Káš, M.; Tkadlecová, M.; Lang, K.; Josef Cvačka, Stibor, I.; P. Lhoták Tetrahedron Lett. 2007, 48, 6620.

16. Iwamoto, H.; Yukimasa, Y.; Fukazawa, Y. Tetrahedron lett. 2002, 43, 8191.

17. Arai, S.; Ohkawa, H.; Ishihara, S.; Shibue, T.; Takeoka, S.; Nishide, H. Bull. Chem. Soc. Jpn. 2005, 78, 2007.

18. (a) Fiammengo, R.; Timmerman, P.; de Jong, F.; Reinhoudt, D. N. Chem. Commun. 2000, 2313. (b) Fiammengo, R.; Timmerman, P.; Huskens, J.; Versluis, K.; Heck, A. J. R.; Reinhoudt, D. N. Tetrahedron 2002, 58, 757. (c) Wei, Y.; Guo, X.; Shuang, S.; Dong, C.; Sun, X.; Wong, M. J. Photochem. Photobio. B 2005, 81, 190.

19. Iki, N.; Horiuchi, T.; Oke, H.; Koyama, K.; Morohashi, N.; Kabuto, C.; Miyano, S. J. Chem. Soc., Perkin Trans. 2001, 2, 2219.

20. (a) Hunter, C. A.; Meah, M. N.; Sanders, J. K. M. J. Am. Chem. Soc. 1990, 112, 5773. (b) Miller, J. R.; Dorough, G. D. J. Am. Chem. Soc. 1952, 74, 3977.

21. Zadmard, R.; Kraft, A.; Schrader, T.; Linne, U. Chem. Eur. J. 2004, 10, 4233.

22. (a) Sari, M. A.; Battioni, J. P.; Dupri, D. L.; Mansuy, D.; Le Pecq, J. B. Biochemistry 1990, 29, 4205. (b) Chauhan, S. M. S.; Gupta, M.; Gulati, A.; Nizar, P. N. H. Ind. J. Chem. 35B 1996, 1267. 